\title{
Transition from School to Work: Experiences of 1980 High School Sophomores Through 1992
}

\section{SUMMARY}

In 1980, there were about $\mathbf{3 . 7}$ million high school sophomores in the United States.

- Fifty percent were women, 13 percent were African Americans, and 8 percent were Hispanic Americans.

- Seventeen percent of high school sophomores left high school before their scheduled graduation date. Slightly more than one in three dropouts had a job when they left high school.

- Forty-five percent graduated from high school on time and enrolled in a postsecondary program the following fall school term.

- The remainder ( 38 percent) graduated from high school on time but left the academic pipeline by not enrolling in a postsecondary program the following fall. Two-thirds of this group held a job instead.

The chances of completing a postsecondary educational program increase the longer students stay continuously in school.

- Only 4 percent of the 1980 high school sophomores who left high school before graduating completed any kind of college degree program by 1992.

- Sixty-three percent of the 1980 sophomores who left high school before graduating had returned to school and earned a high school diploma by 1992. Of the 37 percent who did not complete a high school diploma, 24 percent never returned to high school, while 13 percent returned to high school but did not earn a diploma.

- Eleven percent of the 1980 high school sophomores who completed high school in 1982 but failed to enroll in a postsecondary program the following fall managed to complete a college degree program by 1992.

- Almost two-thirds of the 1980 sophomores who graduated in 1982 and enrolled in a postsecondary program the following fall had received a college degree by 1992 .
Higher levels of educational attainment resulted in higher annual earnings and lower rates of $\mathrm{AEC}$
unemployment. (Table 1.)

- The 1980 sophomores who did not complete high school were more than twice as likely to be unemployed in 1992 and earned 18 percent less annual average income thar those who stopped at a high school diploma.

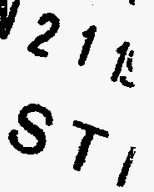

- The returns to postsecondary education are significant1980 sophomores completing a college degree program earned 14 to 35 percent more annual average income than those who stopped at a high school diploma.

Table 1. Unemployment and Income of 1980 High School Sophomores by 1992 Educational

\section{Attainment}

\begin{tabular}{lcc}
$\begin{array}{c}1992 \\
\text { Educational } \\
\text { Attainment }\end{array}$ & $\begin{array}{c}1992 \\
\text { Unemployment } \\
\text { Rate }\end{array}$ & $\begin{array}{c}1991 \\
\text { Average } \\
\text { Annual Income }\end{array}$ \\
\hline Less than High School & $17 \%$ & $\$ 16,100$ \\
High School Diploma & $8 \%$ & $\$ 19,700$ \\
Certificate & $8 \%$ & $\$ 20,000$ \\
Some College & $7 \%$ & $\$ 20,700$ \\
Associate's Degree & $4 \%$ & $\$ 22,500$ \\
Bachelor's Degree & $4 \%$ & $\$ 26,500$
\end{tabular}

Source: ORISE estimates from U.S. Department of Education, "High School and Beyond Fourth Follow-up (Sophomore Cohort) HS\&B: 1992."

Unemployment and earnings are also related to when students leave the educational pipeline.

- The 1980 high school sophomores who left the educational pipeline sooner reduced their probability of completing a postsecondary program.

- Even when they completed a postsecondary program, the early leavers experienced higher unemployment and lower earnings than those who stayed in the pipeline. 


\section{DISCLAMMER}

Portions of this document may be illegible in electronic image products. Images are produced from the best available original document. 


\section{DISCLAIMER}

This report was prepared as an account of work sponsored by an agency of the United States Government. Neither the United States Government nor any agency thereof, nor any of their employees, makes any warranty, express or implied, or assumes any legal liability or responsibility for the accuracy, completeness, or usefulness of any information, apparatus, product, or process disclosed, or represents that its use would not infringe privately owned rights. Reference herein to any specific commercial product, process, or service by trade name, trademark, manufacturer, or otherwise does not necessarily constitute or imply its endorsement, recommendation, or favoring by the United States Government or any agency thereof. The views and opinions of authors expressed herein do not necessarily state or reflect those of the United States Government or any agency thereof. 


\section{School-to-Work Transition of 1980 High School Sophomores}

In 1980 , there were approximately $3,722,000$ high school sophomores.' This report examines the numerous paths that these sophomores took as they moved from school to work, and the labor market consequences of these various paths.

The number of different paths from school to work can be almost unlimited with alternating spells of school, work, back-to-school, movements in and out of the labor force, etc. To examine the effects of these different paths, the $3,722,000$ high school sophomores are divided into three separate transition groups based upon the time that they first left the education pipeline on a full-time basis. (Figure 1.) For example, dropouts are 1980 sophomores who left high school before their scheduled graduation in 1982 and who had no plans to return. Stopouts also left prior to scheduled graduation, but had plans to return to high school and complete their diploma.

Each of these transition groups are examined in 1992 based upon their final level of educational achievement and labor market success. Table 1 contains a summary of the relationship between highest 1992 educational attainment and unemployment and income for the 1980 sophomore class. There is a clear relationship between the level of educational attainment and indicators of job market success such as unemployment rates and income. Dropouts and stopouts who later return to school increase their incomes and lower the probability of unemployment. However, these dropouts/stopouts who return to school still face higher unemployment and lower income than others with similar educational attainment but who did not dropout or stopout.

\section{Transition Group 1: High School Dropouts/Stopouts}

Of the 3.7 million high school sophomores in 1980,17 percent $(636,000)$ dropped out or stopped out prior to regularly scheduled graduation in the spring of 1982 . African Americans and Hispanic Americans are more likely to dropout or stopout than Caucasian Americans, and females are less likely than males.

As can be seen in Figure 2, the majority of the dropout/ stopout group eventually completed more schooling. In terms of 1992 educational attainment, the dropouts/stopouts from the 1980 sophomore class can be divided into three groups: 37 percent did not attain a high school degree, 30 percent completed a high school degree and stopped, and 33 percent enrolled in postsecondary education.

\section{Figure 1. School-to-Work Transition Groups: 1980 High School Sophomores}

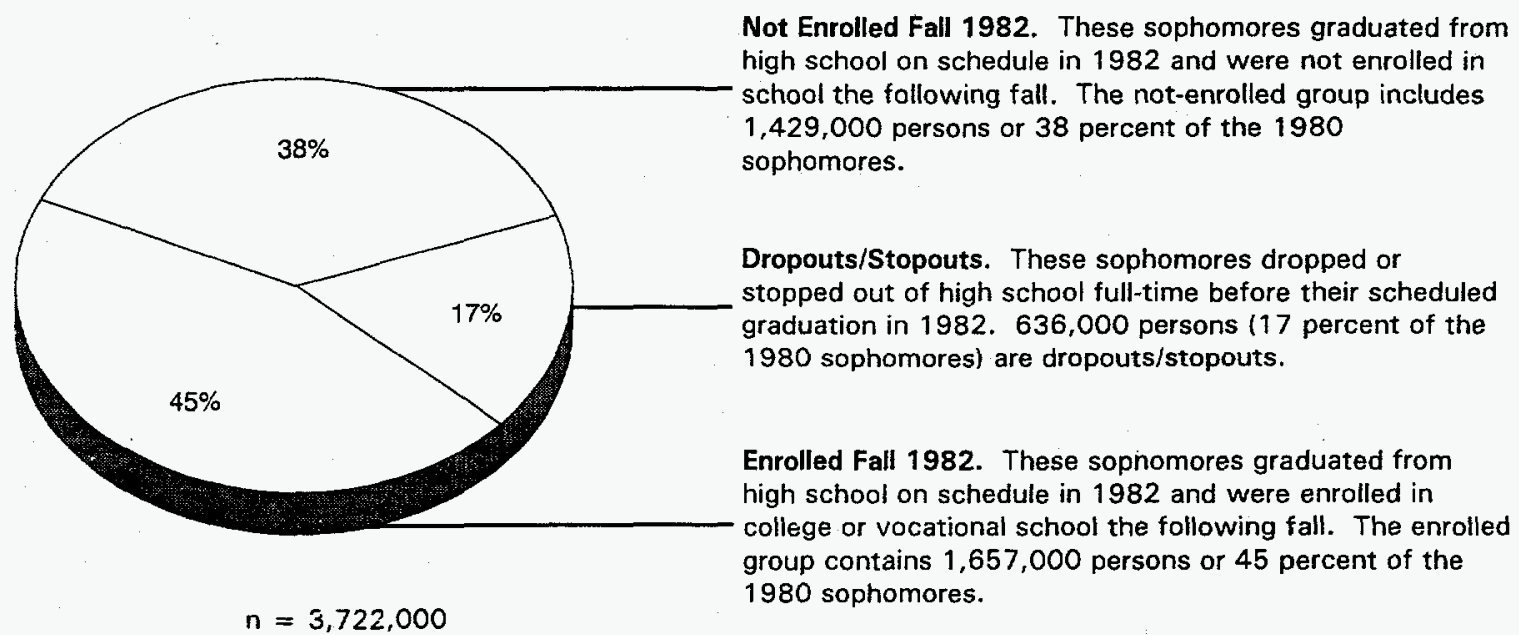

NOTE: This report focuses on the experiences of 1980 high school sophomores. Data on dropout rates, degree attainment, income, etc., are not comparable to current national statistics.

'The data in this report were developed from the National Center for Education Statistics, U.S. Department of Education data set, "High School and Beyond Fourth Follow-up (Sophomore Cohort) HS\&B: 1992." 
Figure 2. 1992 Educational Attainment of 1980 High School Sophomore Dropouts/Stopouts

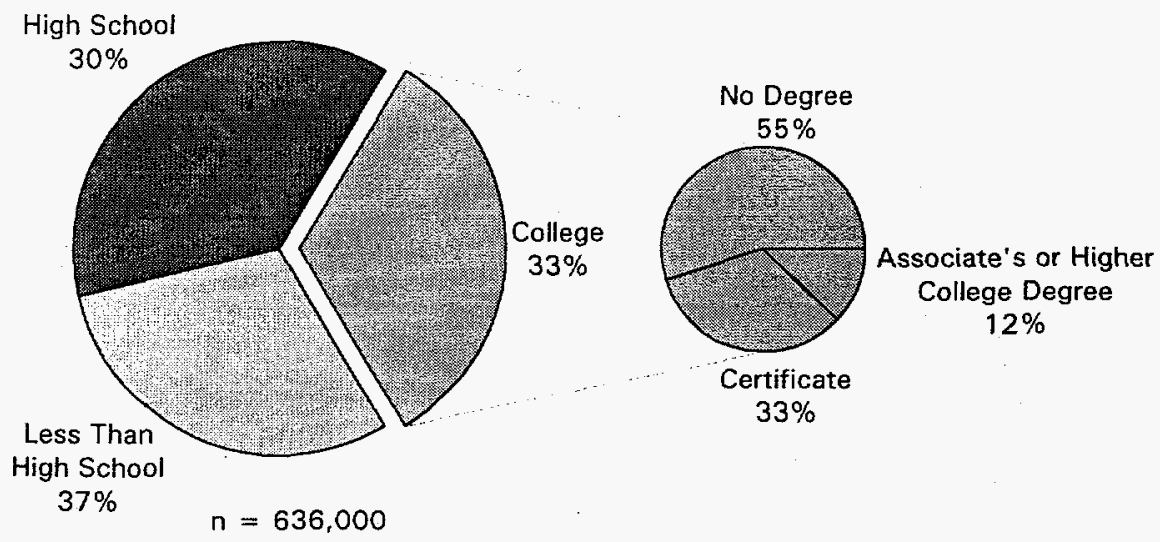

Of the 1980 sophomores who dropped or stopped out, one-third eventually enrolled in postsecondary education. Over one-half of these students failed to complete a certificate or degree. Of the 1980 sophomores who dropped out or stopped out, only one in 25 eventually received an associate's or higher degree by 1992.

Table 2 details unemployment and income for dropouts and stopouts by highest 1992 educational attainment. Going back to school is correlated with both increased earnings and lower unemployment. Completing only a high school diploma did not increase annual earnings greatly for dropouts/stopouts; however, it did substantially reduce unemployment. Receiving at least some postsecondary

Table 2. Unemployment and Income of $1980 \mathrm{High}$ School Sophomore Dropouts/Stopouts by 1992 Educational Attainment

\begin{tabular}{lcc}
$\begin{array}{c}1992 \\
\text { Educational } \\
\text { Attainment }\end{array}$ & $\begin{array}{c}1992 \\
\text { Unemployment } \\
\text { Rate }\end{array}$ & $\begin{array}{c}1991 \\
\text { Average } \\
\text { Annual Income }\end{array}$ \\
\hline Less than High School & $18 \%$ & $\$ 16,200$ \\
High School Diploma & $14 \%$ & $\$ 16,700$ \\
Certificate & $12 \%$ & $\$ 20,300$ \\
Some College & $11 \%$ & $\$ 17,000$ \\
Associate's Degree & $13 \%$ & $\$ 21,900$
\end{tabular}

NOTE: Sample size too small to compute data for bacheior's degree holders.

Source: ORISE estimates from U.S. Department of Education, "High School and Beyond Fourth Follow-up (Sophomore Cohort) HS\&B: 1992." education appears to reduce the likelihood of unemployment further, while completing a postsecondary program raises earnings considerably.

\section{Transition Group 2: 1982 High School Graduates Not Enrolled Fall 1982}

Of the 3.7 million high school sophomores in 1980, 3.1 million graduated in spring of 1982. Of this group, $1,429,000$ (46 percent of the high school graduates) were not enrolled in a postsecondary program the following fall of 1982. This not-enrolled group was in school continuously through high school graduation and then left the academic pipeline, usually to enter the labor force. Females are almost as likely to be in this group as males, while African Americans and Hispanic Americans are more likely than Caucasian Americans to be in this group.

Figure 3 indicates the highest level of 1992 educational attainment for this transition group. Over one-half eventually enrolled in postsecondary education. However, as was the case with the dropout/stopout transition group, over one-half of those who enrolled in postsecondary education failed to complete a degree.

When compared to dropouts/stopouts, the not-enrolled transition group has increased its probability of completing a college degree substantially. By completing a high school diploma on schedule, this probability increases to one in nine even though these persons did not enroll in college immediately after high school graduation. 
Figure 3. 1992 Educational Attainment of 1980 Sophomores Completing High School in 1982 and Not Enrolled in Fall 1982

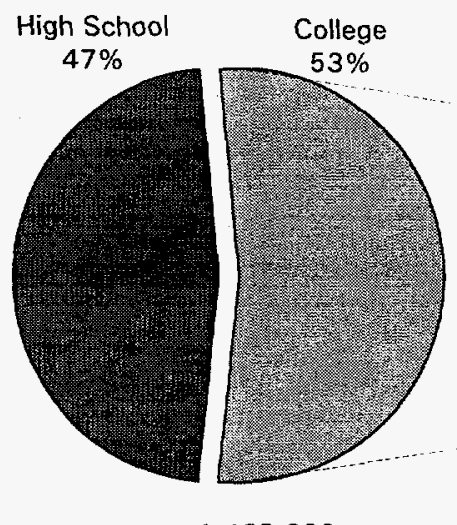

$n=1,429,000$

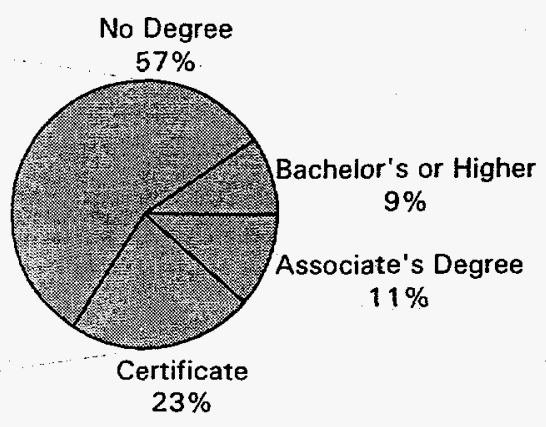

Figure 4. Unemployment of Dropouts/Stopouts and High School Graduates Not Enrolled in Fall 1982 by 1992 Educational Attainment

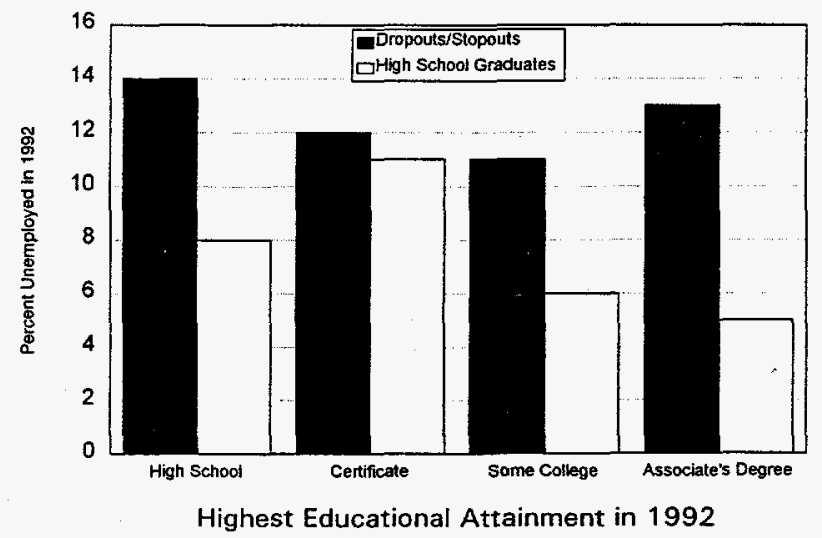

Table 3. Unemployment and Income of 1982 High School Graduates Not Enrolled in Fall 1982 by 1992 Educational Attainment

\section{Transition Group 3: 1982 High School Graduates Enrolled in Fall 1982}

The largest of the three transition groups is the group of 1982 high school graduates enrolled in postsecondary programs in fall of 1982 . Of the 3.7 million 1980 high school sophomerse, 1,657,000 (45 percent) graduated from high school in 1982 and were enrolled in postsecondary education the following fall of 1982 . Females were somewhat more likely to be in this group than males, and African Americans and Hispanic Americans were less likely than Caucasians.

\begin{tabular}{lcc}
$\begin{array}{c}1992 \\
\text { Educational } \\
\text { Attainment }\end{array}$ & $\begin{array}{c}1992 \\
\text { Unemployment } \\
\text { Rate }\end{array}$ & $\begin{array}{c}1991 \\
\text { Average } \\
\text { Annual Income }\end{array}$ \\
\hline High School Diploma & $8 \%$ & $\$ 19,600$ \\
Certificate & $11 \%$ & $\$ 19,600$ \\
Some College & $6 \%$ & $\$ 21,000$ \\
Associate's Degree & $5 \%$ & $\$ 22,800$ \\
Bachelor's Degree & $4 \%$ & $\$ 24,900$ \\
or Higher & &
\end{tabular}

Source: ORISE estimates from U.S. Department of Education, "High School and Beyond Fourth Follow-up (Sophomore Cohort) HS\&B: 1992." 
As can be seen in Figure 5, almost two-thirds of this group eventually completed an associate's or higher degree. This results in the highest degree completion rate among the three transition groups. In addition, one-half of the 1980 sophomores who completed high school on schedule and enrolled in a postsecondary program the following fall eventually finished a four-year degree program by 1992 .

Table 4 contains earnings and unemployment information for 1982 high school graduates enrolled in fall 1982. Not surprisingly, this group has the highest annual earnings of any of the transition groups, with those holding a bachelor's degree or higher earning an average of $\$ 26,700$ in 1991.

\section{Conclusion}

The data show that the majority of students who dropped or stopped out did recover from disruptions in their education and return to school to complete a degree. However, the evidence indicates that the earlier the disruption of education, the lower the probability of completing a college degree. For example, the probability of eventually completing a college degree by 1992 for a high school dropout/stopout is about 4 percent. For those who discontinue schooling immediately after completing a high school degree this probability increases to 11 percent; for those who enroll in college the fall after high school graduation, the probability increases to 65 percent.

The experience of the 1980 sophomores also indicates that early pipeline stopouts diminish the labor market value of their eventual educational attainment. Even those who
Table 4. Unemployment and Income of 1982 High School Graduates Enrolled in Fall 1982

\begin{tabular}{lcc}
$\begin{array}{c}1992 \\
\text { Educational } \\
\text { Attainment }\end{array}$ & $\begin{array}{c}1992 \\
\text { Unemployment } \\
\text { Rate }\end{array}$ & $\begin{array}{c}1991 \\
\text { Average } \\
\text { Annual Income }\end{array}$ \\
\hline Certificate & $3 \%$ & $\$ 20,600$ \\
Some College & $5 \%$ & $\$ 21,700$ \\
Associate's Degree & $3 \%$ & $\$ 22,400$ \\
Bachelor's Degree & $4 \%$ & $\$ 26,700$ \\
or Higher & & \\
Source: $\quad$ ORISE estimates from U.S. Department of Education, \\
\multicolumn{2}{c}{ "High School and Beyond Fourth Follow-up (Sophomore } \\
Cohort) HS\&B: 1992."
\end{tabular}

enrolled in a postsecondary program in the fall of 1982 but failed to complete a degree program still managed to have unemployment rates similar to or sometimes lower than those sophomores who left the educational pipeline earlier and eventually completed a college degree. For example, 1980 sophomores in transition group 3 who failed to complete a degree or certificate program had a 1992 unemployment rate of 5 percent. ("Some College" in Table 4.) Those in transition group 1 who managed to complete an associate's degree suffered from a much higher 1992 unemployment rate of 13 percent. (Table 2.)

Table 5 provides an overall picture of the school-towork transition experience of the 1980 high school sophomores. Overall, 84 percent of the 3.7 million 1980 sophomores were employed in 1992. Clearly, the decisions young people make early in their lives have a major impact on their success in the job market and in their eventual educational attainment.

Figure 5. 1992 Educational Attainment of 1980 Sophomores Completing High School in 1982 and Enrolled in Fall 1982

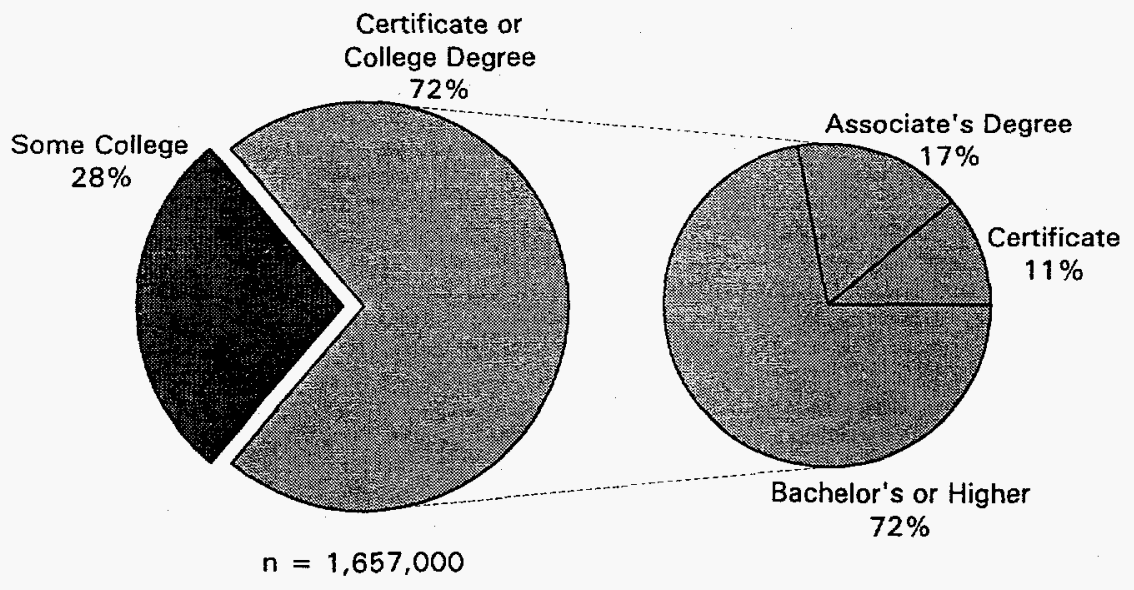


Table 5. School-to-Work Transition Rates of 1980 High School Sophomores (total number $=3,722,000$ )

\section{Dropouts/Stopouts}

1992

\begin{tabular}{lrc}
$\begin{array}{c}1992 \\
\text { Educational } \\
\text { Level }\end{array}$ & Number & $\begin{array}{c}\text { Percent } \\
\text { Employed } \\
\text { in 1992 }\end{array}$ \\
\hline Less than High School & 235,700 & $69 \%$ \\
High School Diploma & 190,800 & $74 \%$ \\
Certificate & 71,100 & $74 \%$ \\
Some College & 116,000 & $76 \%$ \\
Associate's Degree & 22,400 & $71 \%$ \\
$\quad$ or Higher & &
\end{tabular}

Educational

Total

636,000

$72 \%$

\section{High School Graduates Not Enrolled Fall 1982}

\begin{tabular}{lrc}
\multicolumn{1}{c}{$\begin{array}{c}1992 \\
\text { Educational } \\
\text { Level }\end{array}$} & Number & $\begin{array}{c}\text { Percent } \\
\text { Employed } \\
\text { in 1992 }\end{array}$ \\
\hline High School Diploma & 673,100 & $82 \%$ \\
Certificate & 173,000 & $81 \%$ \\
Some College & 428,700 & $84 \%$ \\
Associate's Degree & 86,500 & $89 \%$ \\
Bachelor's Degree & 67,700 & $84 \%$ \\
Total & & $\mathbf{8 3 \%}$
\end{tabular}

1982 High School Graduates Enrolled Fall 1982

\begin{tabular}{lcc}
\multicolumn{1}{c}{$\begin{array}{c}1992 \\
\text { Educational } \\
\text { Level }\end{array}$} & Number & $\begin{array}{c}\text { Percent } \\
\text { Employed } \\
\text { in 1992 }\end{array}$ \\
\hline Certificate & 132,600 & $90 \%$ \\
Some College & 464,000 & $86 \%$ \\
Associate's Degree & 198,800 & $93 \%$ \\
Bachelor's Degree & 861,600 & $90 \%$ \\
Total & $\mathbf{1 , 6 5 7 , 0 0 0}$ & $\mathbf{8 9 \%}$ \\
GRAND TOTAL & $\mathbf{3 , 7 2 2 , 0 0 0}$ & $\mathbf{8 4 \%}$
\end{tabular}

Source: ORISE estimates from U.S. Department of Education, "High School and Beyond Fourth Follow-up (Sophomore Cohort) HS\&B: 1992." 